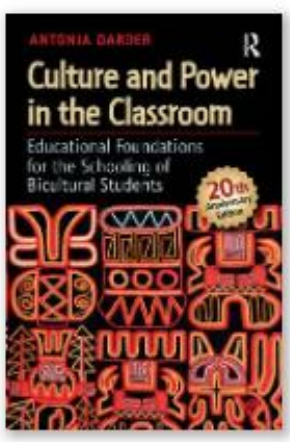

Darder, A. (2016). Culture and power in the classroom: Educational foundations for the schooling of bicultural students (2nd ed.). New York, NY: Routledge. 264 pp., ISBN: 978-161205-070-6. \$50.95 (Digital) or \$40.46 (Print).

\title{
Timely Considerations of Power Discourses in Bicultural Education
}

\author{
Clarisse Halpern ${ }^{1}$ \\ Florida Gulf Coast University
}

Darder's (2016) Culture and power in the classroom celebrated the 20th anniversary of its original publication bringing crucial considerations about bicultural students in the United States education system. By revisiting the roots of the country's issues of social justice, democracy, and humanity, Darder illuminated the educational practices that systematically silenced, marginalized, and excluded voices of underrepresented cultural groups, such as Asians, African Americans, Latinos, Native Americans, and Muslim students. Darder primarily rested on a critical pedagogy perspective that sought emancipation by engaging students in reflection, critical thinking about society, and action to transform their lives and their communities (Freire, 1970; Vossoughi \& Gutiérrez, 2017). Thus, in the next paragraphs, the reader will find a summary of the book's chapters, followed by a review section.

In chapter one, The problem with traditional American pedagogy and practice, Darder discussed the reasons for bicultural students' underachievement according to the lens of conservative and liberal educational discourses. Embedded in positivist ideology, the former blamed individuals' nature and deficit genetic traits as biological predictors of their academic failures, while the latter deems the individuals' environment responsible for their destinies seeking solutions that will equip bicultural students to compete in an unequal system. Thus, Darder explained how factors such as meritocracy, intelligence, teacher expectation, and tracking function as social Darwinism, feeding one another in a vicious cycle that sort and exclude bicultural students in every aspect of their schooling experience. For instance, the myth of meritocracy sells the fallacious idea that the education system is fair and democratic, employing supposedly neutral instruments such as intelligence tests to determine the students' schooling fate objectively. Impacted by test results and tracking, teachers developed negative expectations that inadvertently contributed to bicultural students' negative self-concepts and attitudes, internalizing their "inadequacies" and experiences from school to college and the job market.

In chapter two, The link between culture and power, Darder assertively demonstrated the importance of educators understanding power relations and discourses of truth, ideology, and hegemony based on theories of Foucault, Gramsci, Giroux, and Marx. In line with these theoretical frameworks, she stated that educators must become aware of the mechanisms used by "political power, cultural ideology, and pedagogy [that] result in the domination of subordinate groups" (p. 32), by questioning social practices in schools and supporting bicultural students' needs. By weaving the concepts of power, ideology, and hegemony, Darder explained how truth and knowledge are produced and sustained by a system of power that manifests in schooling discourses, practices, and policies that result in our understanding of the world.

In chapter three, A critical theory of cultural democracy, Darder proposed a liberatory form of education that considers student voices and empowers them to become active social agents in their schooling experiences, in their communities, society, and daily lives. Supported by scholars like Valentine, Rashid, and Solis, who proposed bicultural models and theories on biculturalism, Darder argued for the need for a philosophy of cultural democracy that works for "the right of each individual to be educated in her or his language and learning style... encourag[ing] institutions to develop learning milieus, curriculum materials, and teaching strategies that are sensitive to the child's cultural orientation" (p. 56). In this sense, Darder stressed that educators need to be trained to identify the ideological roots that shape the contradictions and tensions experienced by bicultural students in their efforts to survive various forms of oppression in educational institutions and practices. As a result, educators would be able to work for true cultural democracy in the classroom and school system (Dewey, 1916). 
In chapter four, Testing, inequality, and the brain, Darder criticized the normalization of the testing culture in America and its scientifically-based curriculum, which result in educators' unquestioned acceptance of testing scientific authority. Darder included a discussion on brain development and learning, explaining that children learn best when new knowledge is built upon existing knowledge through "their familiar synaptic connections of cultural consciousness" (p. 74). However, ethnocentric classrooms do not offer bicultural, poor, and working-class children educational experiences that mirror their lived experiences and previous knowledge. Consequently, these children become frustrated, resulting in attention disorders, distrust, and, most often than not, their withdrawal from school. Children, their parents, and their communities should not be blamed for their failures. Instead, Darder suggested blaming the broken education system and its high-risk institutions, institutional policies, and practices.

In chapter five, The foundation for a critical bicultural pedagogy, Darder described the set of philosophical principles of critical pedagogy, based on Apple, Freire, Giroux, McLaren, and Simon, such as cultural politics and economics, dialectical theory and praxis, resistance and counterhegemony, and dialogue and conscientization, and how they align to forge a critical bicultural pedagogy. In her view, these principles help teachers become mindful of how "power, politics, history, and culture [are] intimately and ideologically linked with any theory of education" (p. 82), resulting in the assimilative practices in the traditional American education that pushes bicultural students to the margins. Equipped with these concepts, educators should seek to reform the educational system and change the asymmetrical power relations that subject bicultural and bilingual students subordinate to the dominant group, fostering liberatory bicultural educational practices.

Up until this point, Darder built the theoretical foundation to understand the praxis of critical bicultural pedagogy in the final two chapters. So, in chapter six, Creating the conditions for cultural democracy in the classroom, Darder clarified that there is no recipe to put liberatory pedagogy into practice; therefore, the reader will not find models or how-to manuals for duplication and application. A one-size-fits-all manual is not adequate for critical bicultural education as its emancipatory essence requires a contextual and conditional practice that is in line with the "multiplicity of contexts [educators] find in their classrooms [that] shape environments according to the lived experiences and actual educational needs of their students" (p. 105). Questions of bilingualism, authority, and ideas for transforming the context of teaching were presented to help educators become aware of the common issues they will encounter when adopting a critical bicultural pedagogy perspective. Ultimately, Darder encouraged educators to become aware of the theoretical forces described in the previous chapters and how they shape educational practices, to break free from the traditional reductionist and restrictive role of mere technicians to become emancipated critical bicultural educators.

Finally, in chapter seven, Forging a critical bicultural praxis: Stories from the field, Darder provided examples of how critical bicultural pedagogy must be lived in which educators work for their students emancipation and empowerment as individuals and members of society. To that end, she presented 14 short essays written by practitioners who applied the ideas presented in this book to their unique contexts, constructing a critical bicultural praxis within traditional and nontraditional educational settings.

\section{Review}

Words wield power through discourses as well as socio-cultural, political, and historical contexts (Foucault, 1980) capable of legitimizing or undermining people's “culture, values, heritage, language, knowledge, and lived experiences" (Darder, 2016, p. 29). Darder was well aware of that in her determination to use 'bicultural' to describe students that experience a system of inequalities. She knew that descriptors like 'minorities' or 'underrepresented groups' carry a load of the negative connotation that disempowers and suggest weaknesses rather than give bicultural students a chance to be described under a positive light and stand against a historical subordinate relationship with dominant groups. Therefore, Darder challenged the legitimacy of accepted ideas about bicultural students perpetuated and supported by institutions of power (Foucault, 1980) such as schools that produce, make, and shape (Wandel, 2001) how these students are perceived and, ultimately, (un)served by the education system. In this vein, her proposition of a critical bicultural pedagogy also aligns with critical theories representing a "radical rupture with traditional ideas" (Marx \& Engles, 2013, p. 29).

When bicultural students' voices are not heard, they learn their roles and place in a so-called meritocratic society (Steinberg \& Kincheloe, 2001) and are led to believe they are intellectually inferior to those in power. In this manner, one can say that the ideas about bicultural students are the result of a power discourse; a power that produces realities (Foucault, 1979) about these students' cultural and linguistic backgrounds, families, life histories, abilities, ambitions, dreams, and needs. Conversely, Darder's book overflows with concepts that aim to have bicultural students' voices heard because they have been silenced as humans and denied agency over their lives, schooling experiences, and future possibilities for too long. Consequently, notably Darder's language aimed to praise and advocate for bicultural students as a way to reveal the truth (Derrida, 1978; Foucault, 1965) about their needs and experiences, at the same time as it unmasked the truth about the backdrop of social, cultural, historic, political, and economic forces 
that broadly affect these students' schooling and societal experiences. To that end, Darder provided a robust theoretical foundation to understand the powerful forces at play that profoundly affect bicultural students' schooling experiences, as well as means to have educators reflect on their practices to act to help their students become agents of change in school and society (Cook-Sather, 2018; Fielding, 2001; Freire, 1970).

To give further legitimacy to her ideas, Darder cited numerous relevant scholars on critical pedagogy, power relations, and social justice in education such as Apple, Freire, Giroux, Foucault, Gay, and Nieto. In this sense, Darder pointed out the origins of her ideas and propositions based on these scholars and their ideas, allowing the reader to understand the concepts under study. Also, citing the Frankfurt School tenets like Marcuse, Horkheimer, Adorno, and Held, Darder meant to elucidate how the positivist rationality redefined the understanding of culture as independent and individualistic as well as politically, historically, and economically unrelated. Also, her theoretical discussions explained why discussions about the interrelations of power and culture in teacher education programs tend to be avoided, and schools become "sites where ideologies are produced, reproduced, and perpetuated in society" (p. 31). In this sense, the language normally used to describe bicultural students characterizes a negative application of power that tend to leave critical theorists powerless to act against it (Wandel, 2001). Consequently, the dominant group secures its hegemonic position, while the subordinate one has its culture, language, heritage, lived experiences, knowledge, and values marginalized and invalidated. Thus, the book contributes to develop critical thinking, a significant step in moving toward transformative and emancipatory practices. With a strong theoretical foundation, scholars and practitioners in education expand their perceptions of the world, their abilities to critically understand, reflect, and discuss the forces that drive the backstage of educational practices. Consequently, educators become less naïve and less likely to reproduce the current order, and more likely to pursue critical bicultural pedagogy approaches to their practices.

Nevertheless, important considerations must be made about teaching critical bicultural pedagogy in teacher education programs and their application in curricular activities and schooling practices. As Darder mentioned, critical discussions tend to be avoided in teacher education programs, transforming educators into mere technicians (Zeichner, 2008), and, for that reason, critical bicultural pedagogy does not aim to provide models to teach pre-service and inservice teachers how to apply its concepts to maintain its emancipatory essence. Nonetheless, most often than not, when individuals are presented with a robust set of philosophical issues such as those in Darder's book, they need time to digest its content and guidance to put them into practice. With that in mind, Darder provided a full chapter with 14 short essays that depict critical bicultural pedagogy applied in diverse settings, discussions, and practices. Despite providing inspiring examples that range from works with bicultural families, designing a graduate program in Urban Teaching, to learning to value themselves (the authors) as bicultural educators, they lack details of how the authors applied the concepts to allow some replication. Though I am not suggesting that technical procedures or how-to manuals should be the goal of critical bicultural pedagogy, but recommending examples that offer a more thorough description of how practitioners implement activities, discussions, curricular changes, and others to put critical bicultural pedagogy in action.

Novice and experienced practitioners, depending on the degree of their exposure to these concepts, may need guidance (if not supervision) to implement changes to their practices, despite the existing resistance in the system. In this sense, the cases presented in the book could have included not only what motivated the authors to write the essays, but detailed procedures of their experiences implementing critical bicultural pedagogy to their contexts, reflecting on what was done, how it was done, the limits and possibilities of these experiences. That could help other practitioners exercise ideas and alternatives to apply those procedures to other contexts.

Another essential consideration resides in the ability of the capitalist and neoliberalist systems to self-regulate, always finding a way to restore its balance when it is confronted with change (Gatto, 2005; Halpern, 2018; Hoyle, 1985). In this sense, because of its disruptive and emancipatory nature, the implementation of critical bicultural pedagogy seems to stay restricted to the fringes of the system, the microcosm of teaching and learning experiences. In this case, the few that got immersed in its theory and dare to change the system do it within their classrooms and daily practices; while others although exposed to its concepts may not know how to do it, and many more repeat the prevailing order because it is already known and accepted as schooling practices and experiences.

Ultimately, the relevance of Darder's book is that it calls attention to how words, meanings, perceptions, thoughts, and actions contaminate educational practices oriented by hegemonic worldviews that value Eurocentric discourses and practices while discriminates against others. Darder's book takes the reader into a deep reflection about the modus operandi of the American education system concerning bicultural students, often obscured by ideology and systems of power that "entrap our sensibilities, and colonize our everyday existence" (p. 29), and encourages educators to take on a life-long commitment in favor of these students, their stories, their voices, their communities, and their selves. 


\section{References}

Cook-Sather, A. (2018). Listening to equity-seeking perspectives: How students' experiences of pedagogical partnership can inform wider discussions of student success. Higher Education Research and Development, 37(5), 923-936.

Darder, A. (2016). Culture and power in the classroom: Educational foundations for the schooling of bicultural students (2nd ed.). New York, NY: Routledge.

Derrida, J. (1978). Writing and difference (A. Bass, Trans.). Chicago, IL: The University of Chicago Press.

Dewey, J. (1916). Democracy and education. New York, NY: The Macmillan Company.

Fielding, M. (2001). Students as radical agents of change. Journal of Educational Change, 2, 123-141.

Foucault, M. (1965). Madness and civilization: A history of insanity in the Age of Reason. Trans. Richard Howard. New York, NY: Vintage Books.

Foucault, M. (1979). Discipline and punish: The birth of the prison (A. Sheridan, Trans.). New York, NY: Random. (Original work published in 1975).

Foucault, M. (1980). Questions de la méthode [Questions of the method]. In M. Perrot (Ed.), L'impossible prison: Recherches sur le système pénitentiaire au XIXe siècle [The impossible prison: Research on the penitentiary system in the nineteenth century]. Paris, France: Éditions du Seuil.

Freire, P. (1970). Pedagogia do oprimido [Pedagogy of the oppressed]. Rio de Janeiro, Brazil: Paz e Terra.

Gatto, J. T. (2005). Dumbing us down: The hidden curriculum of compulsory schooling. Gabriola Island, Canada: New Society Publishers.

Halpern, C. (2018). The gears of the hidden curriculum revisited. Journal of Curriculum Theorizing, 33(1), 40-44.

Hoyle, E. (1985). [Review of the book Structuralism and Education, by Rex Gibson]. British Journal of Educational Studies, 33(2), 183-185. doi:10.2307/3121513

Marx, K., \& Engels, F. (2013). The Communist Manifesto (2nd ed.). New York, NY: W.W. Norton \& Co.

Steinberg, S. R., \& Kincheloe, J. L. (2001). Setting the context for critical multi/interculturalism: The power blocs of class elitism, White supremacy, and patriarchy. In S. R. Steinberg (Ed.), Multi/Intercultural conversations: A reader (pp. 3-30). New York, NY: P. Lang.

Vossoughi, S., \& Gutiérrez, K. D. (2017). Critical pedagogy and sociocultural theory. In I. Esmonde \& A. N. Booker (Eds.), Power and privilege in the learning sciences: Critical and sociocultural theories of learning (pp. 139161). New York, NY: Routledge.

Wandel, T. (2001). The power of discourse: Michel Foucault and critical theory. Cultural Values, 5(3), $368-382$. doi:10.1080/14797580109367237

Zeichner, Z. M. (2008). Uma análise crítica sobre a "reflexão" como conceito estruturante na formação docente [A critical analysis of reflection as a goal for teacher education]. Educação \& Sociedade, 29(103), 535-554. doi:10.1590/S0101-73302008000200012. 